\title{
Production of extracellular alkaline protease by new halotolerant alkaliphilic Bacillus sp. NPST-AK15 isolated from hyper saline soda lakes
}

\author{
Abdelnasser S.S. Ibrahim a,b,*, Ali A. Al-Salamah ${ }^{\text {a }}$, Yahya B. Elbadawi ${ }^{\text {a }}$, \\ Mohamed A. El-Tayeb ${ }^{a}$, Shebl Salah Shebl Ibrahim ${ }^{c}$ \\ a Department of Botany and Microbiology, College of Science, King Saud University, Riyadh 11451, Saudi Arabia \\ ${ }^{\mathrm{b}}$ Department of Chemistry of Natural and Microbial Products, National Research Center, El-Buhouth St., Dokki, Cairo 12311, Egypt \\ c College of Science, Center of Excellency for Biotechnology, King Saud University, Riyadh 11451, Saudi Arabia
}

\section{A R T I C L E I N F O}

\section{Article history:}

Received 12 January 2015

Accepted 10 March 2015

Available online 11 April 2015

\section{Keywords:}

Alkaline protease

Alkalophiles

Bacillus sp.

Fermentation

Optimization

\begin{abstract}
A B S T R A C T
Background: Alkaline proteases are among the most important classes of industrial hydrolytic enzymes. The industrial demand for alkaline proteases with favorable properties continues to enhance the search for new enzymes. The present study focused on isolation of new alkaline producing alkaliphilic bacteria from hyper saline soda lakes and optimization of the enzyme production.

Results: A new potent alkaline protease producing halotolerant alkaliphilic isolate NPST-AK15 was isolated from hyper saline soda lakes, which affiliated to Bacillus sp. based on 16S rRNA gene analysis. Organic nitrogen supported enzyme production showing maximum yield using yeast extract, and as a carbon source, fructose gave maximum protease production. NPST-AK15 can grow over a broad range of $\mathrm{NaCl}$ concentrations (0-20\%), showing maximal growth and enzyme production at $0-5 \%$, indicated the halotolerant nature of this bacterium. $\mathrm{Ba}$ and $\mathrm{Ca}$ enhanced enzyme production by 1.6 and 1.3 fold respectively. The optimum temperature and $\mathrm{pH}$ for both enzyme production and cell growth were at $40^{\circ} \mathrm{C}$ and $\mathrm{pH} 11$, respectively. Alkaline protease secretion was coherent with the growth pattern, started at beginning of the exponential phase and reached maximal in mid stationary phase $(36 \mathrm{~h})$.

Conclusions: A new halotolerant alkaliphilic alkaline protease producing Bacillus sp. NPST-AK15 was isolated from soda lakes. Optimization of various fermentation parameters resulted in an increase of enzyme yield by 22.8 fold, indicating the significance of optimization of the fermentation parameters to obtain commercial yield of the enzyme. NPST-AK15 and its extracellular alkaline protease with salt tolerance signify their potential applicability in the laundry industry and other applications.
\end{abstract}

(c) 2015 Pontificia Universidad Católica de Valparaíso. Production and hosting by Elsevier B.V. All rights reserved.

\section{Introduction}

Proteases (EC 3.4.21) are a large group of hydrolytic enzymes that catalyze the hydrolysis of the proteins by cleavage of the peptide bonds between the amino acid residues in other proteins [1]. Proteases constitute one of the most important groups of industrial enzymes, accounting for more than $65 \%$ of total industrial enzyme market $[2,3]$. Moreover, microbial proteases constitute approximately $40 \%$ of the total worldwide production of enzymes [4,5]. Alkaline proteases, with high activity and stability in high alkaline range, are interesting for several bioengineering and biotechnological applications. However, their main application is in the detergent industry, accounting for approximately $30 \%$ of the total world enzyme production [6] because the $\mathrm{pH}$ of laundry detergents is in the range of

\footnotetext{
* Corresponding author.

E-mail address: ashebl@ksu.edu.sa (A.S.S. Ibrahim).

Peer review under responsibility of Pontificia Universidad Católica de Valparaíso.
}

9.0-12.0. Alkaline proteases are used in detergent formulations, with other hydrolytic enzymes, as cleaning additives to facilitate the breakdown and release of proteins [7,8]. In addition, alkaline proteases have various other industrial applications including leather, pharmaceuticals, protein processing, foods, diagnostic reagents, soy processing, peptide synthesis industries, and extraction of silver from used X-ray film $[9,10]$. Therefore, the industrial demand for highly active alkaline proteases with high specificity and stability of $\mathrm{pH}$, temperature, and organic solvents continues to enhance the search for new enzymes [11].

Extremophiles are microorganisms that have evolved to live in a variety of unusual habitats, the so-called extreme environments. They fall into a number of different classes including halophiles, alkalophiles, thermophiles, psychrophiles, and others [12]. The groups of bacteria that can grow under alkaline conditions in the presence of $\mathrm{NaCl}$ are referred to as halotolerant alkaliphiles and haloalkaliphiles. The dual extremity of these extremophiles, high $\mathrm{pH}$, and salt concentration make them attractive strains for exploration of novel 
alkaline proteases for biotechnological potential [13,14]. One of the major natural habitats of alkaliphilic bacteria are hyper saline soda lakes which represent the major types of naturally occurring highly alkaline environments $(\mathrm{pH}>11.5)$, in addition to high $\mathrm{NaCl}$ concentration [15]. Despite the worldwide prevalence of the soda lakes, few of such lakes have been explored from the microbiological point of view as a result of their inaccessibility. One of those environmental niches, which have not been studied in details, are Wadi El-Natrun Valley hyper saline soda lakes, located in northern Egypt. The features of Wadi EL-Natrun Valley created an ecosystem considered as rich sources for isolation of alkaliphilic, haloalkaliphilic, and thermo-alkaliphilic microorganisms [15,16,17].

In order to obtain commercially viable yields, it is essential to optimize fermentation media for the growth and protease production. Considering the above mentioned facts, the present study focused on isolation of new alkaline producing alkaliphilic bacteria from Wadi El-Natrun hyper saline soda lakes, and optimization of the enzyme production by investigation of the effect of various physio-environmental parameters.

\section{Materials and methods}

\subsection{Collection of soil and water samples}

Sediment and water samples were collected from hyper saline soda lakes in Wadi El-Natrun Valley that are located in northern Egypt (Fig. 1). The Valley contains alkaline inland saline lakes in an elongated depression approximately $90 \mathrm{~km}$ northwest of Cairo (capital of Egypt). The average length of the valley is nearly $60 \mathrm{~km}$, and its average width is approximately $10 \mathrm{~km}$. Wadi El-Natrun Valley extends in a northwest by southeast direction between latitude $30^{\circ} 15^{\prime}$ North and longitude $30^{\circ} 30^{\prime}$ East. The bottom of the Valley is $23 \mathrm{~m}$ and $38 \mathrm{~m}$ below sea level, and water level of Rosetta branch of the Nile, respectively [18]. Sediment and water samples were collected from various hyper saline soda lakes in sterile containers, kept at $4^{\circ} \mathrm{C}$, and transferred within few $\mathrm{d}$ to the laboratory at King Saud University (Riyadh, Saudi Arabia).

\subsection{Isolation of alkaline protease producing alkaliphilic bacteria}

Isolation of alkaline protease producing alkaliphilic bacteria was carried out using Horikoshi-I alkaline medium with some modification [15]. The alkaline agar medium ( $\mathrm{pH} 10.5)$ contained glucose $(10 \mathrm{~g} / \mathrm{L})$, yeast extract $(5 \mathrm{~g} / \mathrm{L})$, peptone $(5 \mathrm{~g} / \mathrm{L}), \mathrm{K}_{2} \mathrm{HPO}_{4}(1 \mathrm{~g} / \mathrm{L}), \mathrm{Mg}_{2} \mathrm{SO}_{4} \times 7 \mathrm{H}_{2} \mathrm{O}$ $(0.2 \mathrm{~g} / \mathrm{L}), \mathrm{NaCl}(50 \mathrm{~g} / \mathrm{L}), \mathrm{Na}_{2} \mathrm{CO}_{3}(10 \mathrm{~g} / \mathrm{L})$, and agar $(15 \mathrm{~g} / \mathrm{L})$, in addition to $10 \%(\mathrm{w} / \mathrm{v})$ skim milk, as an indicator of alkaline protease production [2]. The skim milk, glucose, and $\mathrm{Na}_{2} \mathrm{CO}_{3}$ were autoclaved separately before the addition to the medium. Sediment and water samples were suspended and serially diluted in a $10 \%(\mathrm{w} / \mathrm{v}) \mathrm{NaCl}$ solution prepared in $50 \mathrm{mM}$ glycine- $\mathrm{NaOH}$ buffer, $\mathrm{pH}$ 10. Aliquots ( $200 \mu \mathrm{L}$ ) of various dilutions were spread on the alkaline agar medium and incubated at different temperatures for several $\mathrm{d}$. The formation of clearing zone around the colonies resulted from the production of alkaline protease, and subsequent casein hydrolysis was considered as an initial indication of enzyme activity $[2,11]$. Positive strains were streaked several times on fresh plates until single uniform colonies were obtained, and glycerol stocks of each strain were prepared and stored at $-80^{\circ} \mathrm{C}$ till further analysis.

\subsection{Bacterial identification}

The selected strain was identified using 16S rRNA gene sequence analysis as per the standard protocols [19]. The bacterial isolate was grown overnight in $5 \mathrm{~mL}$ alkaline broth medium. Total DNA was extracted using DNeasy Blood \& Tissue Kits (Qiagen, USA) according to the manufacturer's instructions. Eubacterial-specific forward primer: 16F27 (5'-AGA GTT TGA TCC TGG CTC AG-3'), and reverse primer: 16R1525 (5'-AAG GAG GTG ATC CAG CCG CA-3') were used to amplify 16 S rDNA gene [20,21]. PCR amplification was performed in a final reaction volume of $50 \mu \mathrm{L}$. The reaction mixture contained $2 \times 25 \mu \mathrm{L}$ GoTaq ${ }^{\circledR}$ Green Master Mix (Promega, USA), $1 \mu \mathrm{L}$ forward primer $(10 \mu \mathrm{M}), 1 \mu \mathrm{L}$ reverse primer $(10 \mu \mathrm{M}) 5 \mu \mathrm{L}$ DNA template (200 ng) and $18 \mu \mathrm{L}$ nuclease-free water. The PCR reaction run for 35 cycles in a DNA thermal cycler, under the following thermal profile: Initial denaturation at $95^{\circ} \mathrm{C}$ for $5 \mathrm{~min}$, denaturation at $95^{\circ} \mathrm{C}$ for $1 \mathrm{~min}$, primers annealing at $52^{\circ} \mathrm{C}$ for $1 \mathrm{~min}$, and extension at $72^{\circ} \mathrm{C}$ for $1.5 \mathrm{~min}$. The final cycle included extension for $10 \mathrm{~min}$ at $72^{\circ} \mathrm{C}$ to ensure full extension of the products. PCR products were ran on agarose gel electrophoresis, and then purified using a QIAquick gel extraction kit (Qiagen, USA). The purified 16S-rDNA was sequenced using an automated sequencer (Macrogen, Korea), and the obtained sequence was aligned with reference 16S-rDNA sequences available in NCBI homepage (National Center for Biotechnology Information) using the BLAST algorithm.

\subsection{Inoculum preparation and alkaline protease production}

Colonies of the positive strains, showing clearing zone around their margins, were transferred to $50 \mathrm{~mL}$ glass tube containing $5 \mathrm{~mL}$ of the liquid production medium, with the same composition as the solid medium, except for the presence of agar and skim milk, and incubated overnight at $40^{\circ} \mathrm{C}$ in shaking incubator (150 rpm). This culture was used to inoculate $250 \mathrm{~mL}$ Erlenmeyer flasks containing $50 \mathrm{~mL}$ of the same medium and cultivated under the same conditions for approximately $24 \mathrm{~h}$. Cells and insoluble materials were removed by centrifugation at $6000 \times \mathrm{g}$ for $15 \mathrm{~min}$ at $4^{\circ} \mathrm{C}$, and cell-free supernatant
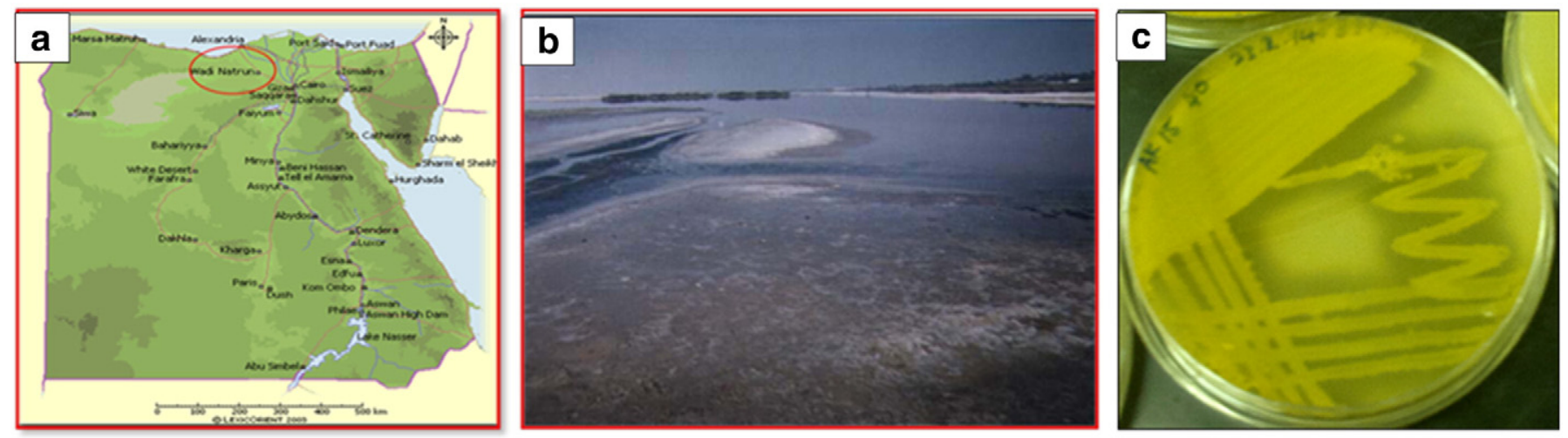

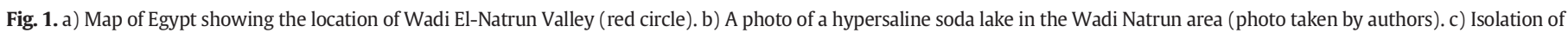
alkaline protease alkaliphilic bacteria using modified Horikoshi-I agar plate containing skim milk. The clear zone indicated casein hydrolysis due to alkaline protease production. 
was filtered through a $0.45 \mu \mathrm{m}$ pore-size membrane filter, and the alkaline protease activity was measured.

\subsection{Assay of alkaline protease}

Alkaline protease activity was measured using previously reported method with some modifications [22]. $0.5 \mathrm{~mL}$ of $50 \mathrm{mM}$ glycine- $\mathrm{NaOH}$ $(\mathrm{pH} 10.0)$ containing $1 \%(\mathrm{w} / \mathrm{v})$ casein and $10 \mathrm{mM} \mathrm{CaCl}_{2}$ was pre-incubated for $5 \mathrm{~min}$ at $50^{\circ} \mathrm{C}$. Then, $0.5-\mathrm{mL}$ aliquot of suitably diluted culture supernatant was mixed with the substrate solution, and incubated for $20 \mathrm{~min}$ at $50^{\circ} \mathrm{C}$. After that, the reaction was terminated by the addition of $0.5 \mathrm{~mL}$ of $20 \%(\mathrm{w} / \mathrm{v}$ ) trichloroacetic acid (TCA). The mixture was allowed to stand at room temperature for $15 \mathrm{~min}$ and centrifuged at $6000 \times \mathrm{g}$ for $15 \mathrm{~min}$ to remove the precipitate. The acid-soluble materials were estimated using Lowry method [23]. Control was prepared by adding TCA before adding the enzyme. A standard curve was generated using solutions of $0-100 \mu \mathrm{g} / \mathrm{mL}$ tyrosine. One unit of protease activity was defined as the amount of enzyme required to liberate $1 \mu \mathrm{g}$ of tyrosine per minute under the experimental conditions. All enzyme assay experiments were carried out in triplicate, and the mean values were recorded.

\subsection{Optimization of the production medium}

\subsubsection{Effect of carbon source}

To investigate the influence of different carbon sources on the bacterial growth and alkaline protease production by the selected strain, glucose in the production medium was substituted with other carbon sources, including $1 \%(\mathrm{w} / \mathrm{v})$ xylose, glucose, galactose, fructose, maltose, lactose, sucrose, starch, and wheat bran as a sole source of carbon. The various carbon sources were autoclaved separately and added to the medium on an equal carbon basis. Furthermore, the effects of different concentrations ( $0-4 \%)$ of the best carbon source were also investigated. The growth and enzyme activity were monitored after $24 \mathrm{~h}$ incubation at $40^{\circ} \mathrm{C}$, under shaking conditions $(150 \mathrm{rpm})$. All experiments and enzyme assays were performed in triplicate, and the mean values were reported.

\subsubsection{Effect of nitrogen source}

The effect of different nitrogen sources on the bacterial growth and alkaline protease production by the selected isolate was investigated by substituting the peptone and yeast extract in the production medium (Horikoshi-1), with different sources of organic and inorganic nitrogen sources $(0.5 \%, \mathrm{w} / \mathrm{v})$. Organic nitrogen sources included peptone, yeast extract, tryptone, alkali soluble casein, insoluble casein, skim milk, gelatin, and beef extract; while inorganic nitrogen sources included ammonium nitrate, ammonium sulfate, sodium nitrate, and urea. Furthermore, the effects of different concentrations (0-2\%) of nitrogen source that support maximum enzyme yield were also investigated. The growth and enzyme activity were measured after $24 \mathrm{~h}$ incubation at $40^{\circ} \mathrm{C}$, under shaking conditions of $150 \mathrm{rpm}$.

In addition to carbon and nitrogen source testing, the effects of $\mathrm{NaCl}$ concentration (0-25\%), and various metal ions, including $\mathrm{Mg}^{+2}, \mathrm{Mn}^{+2}, \mathrm{Zn}^{+2}, \mathrm{Ca}^{+2}, \mathrm{Cu}^{+2}, \mathrm{Co}^{+2}, \mathrm{Fe}^{+2}$, and $\mathrm{Ba}^{+2}(1 \mathrm{mM}$, $5 \mathrm{mM}$, and $10 \mathrm{mM}$ ), on the bacterial growth and alkaline protease production were investigated.

\subsubsection{Effect of temperature, $\mathrm{pH}$, and aeration}

The influence of temperature on the bacterial growth and alkaline protease production by the selected strain was investigated by varying the growth temperature $\left(30-60^{\circ} \mathrm{C}\right)$, keeping the other parameters constant. Similarly, in order to investigate the influence of initial $\mathrm{pH}$ of the production medium on growth and protease production, the isolate was grown in medium with different $\mathrm{pH}(5.0-12.0)$ at optimum growth temperature. The growth and enzyme activity were measured as described above. Moreover, the effect of the aeration level during fermentation on growth and protease production was studied by incubating the culture in shaking incubators with different rpm values which ranged from zero (static) to $250 \mathrm{rpm}$.

\subsection{Growth kinetics and proteases production}

Colonies of the selected isolate were transferred to $250 \mathrm{~mL}$ Erlenmeyer flasks containing $50 \mathrm{~mL}$ of the optimized production medium and incubated at $40^{\circ} \mathrm{C}$ under orbital shaking (200 rpm). These cultures were used to inoculate 1 L flasks containing $250 \mathrm{~mL}$ of the same medium and cultivated under the same conditions. Samples $(1 \mathrm{~mL})$ were withdrawn at $2 \mathrm{~h}$ intervals up to $48 \mathrm{~h}$ for the measurement of growth and alkaline protease activity. The samples were centrifuged at $6000 \times \mathrm{g}$ at $4^{\circ} \mathrm{C}$, and the pellets obtained were washed twice using Tris buffer ( $\mathrm{pH} \mathrm{8}$ ), and resuspended in $1 \mathrm{~mL}$ of the same buffer. Absorbance was measured at $600 \mathrm{~nm}$ against Tris Buffer ( $\mathrm{pH} 7$ ) as blank, and was reported as growth of the bacterium. The cell-free supernatant was filtered through a $0.45-\mu \mathrm{m}$ pore-size membrane filter, and the alkaline protease activity was measured as described above. The triplicate of each period was taken to calculate the growth and enzyme activity and the mean values were reported.

\subsection{Statistical analysis}

All the experiments, enzyme assay, and cells growth measurement were carried out in triplicate, and the standard deviation for each test was calculated using SPSS 14.0 [14]. The standard deviations $(n=3)$ are indicated as error bars.

\section{Results and discussion}

\subsection{Isolation and identification of the microorganism}

The sediment and water samples were spread over the modified Horikoshi-I agar medium containing skim milk as an indicator of protease production. After the incubation period, morphologically distinct colonies were observed on the agar plates. Some of the colonies were showing zone of hydrolysis indicating the production of extracellular alkaline protease (Fig. 1). Individual colonies were purified through repeated streaking on fresh agar plates. The extensive screening process resulted in isolation of 15 alkaline protease producing alkaliphilic bacterial strains that showed clear zone around their colonies. All the positive isolates were cultivated in alkaline production liquid medium, and the proteolytic activity was measured. The strain NPST-AK15 showing the highest alkaline protease activity $(55.1 \mathrm{U} / \mathrm{mL})$ was selected for further investigation.

Strain NPST-AK15 is a Gram-positive, spore former, catalase-positive, oxidase-negative bacterium, which forms yellow colonies on the agar surface. Cells were motile, short rods, with lengths of about $1.5 \mu \mathrm{m}$ and $0.5 \mu \mathrm{m}$ in diameter, and the cells existed as single, paired or short chain (Fig. 2). NPST-AK15 can utilize several carbon sources including glycogen, mannose, glucose, xylose, citric acid, and starch. The growth of NPST-AK15 occurred with $0-20 \%$ (w/v) $\mathrm{NaCl}$ (optimally at $0-5 \%$ ), at $\mathrm{pH} 7.0-12.0$ (optimally at $\mathrm{pH} 11$ ) and can grow at temperature between $25^{\circ} \mathrm{C}$ and $55^{\circ} \mathrm{C}$ (optimally at $40^{\circ} \mathrm{C}$ ). Considering the physiological and biochemical tests performed, and according to Bergey's Manual of Determinative Bacteriology, the strain was identified as Bacillus sp. [14]. The organism was further identified by 16S rRNA gene sequencing having a length of 1449 bp nucleotides. Phylogenetic analysis of its 16S rRNA gene sequence revealed that NPST-AK15 is affiliated with the genus Bacillus and closely related to several alkaliphilic Bacillus sp. with 99\% similarity (Fig. 3). This sequence was deposited in GenBank with accession number KP295749, and the isolate was tentatively named as Bacillus sp. strain NPST-AK15. 

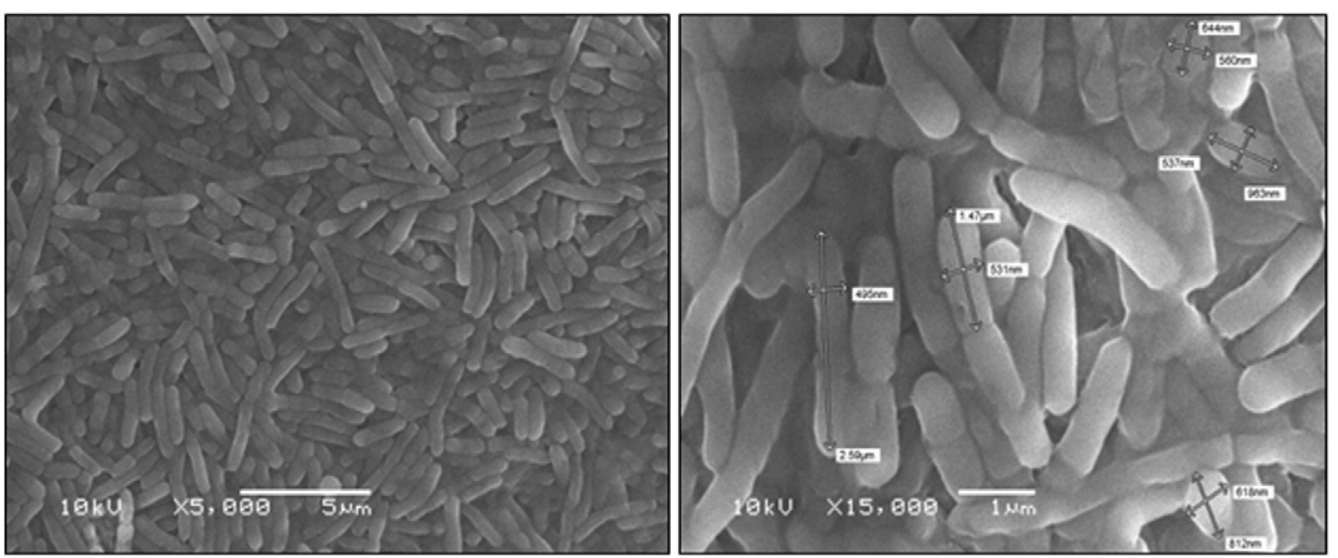

Fig. 2. Scanning electron microscope (SEM) images of strain NPST-AK15.

\subsection{Optimization of alkaline protease production}

The small productivity of enzymes and metabolites from extremophiles represents one of the major bottlenecks in their industrial applications [17]. It has been established that the production of alkaline protease is highly affected by media composition, viz. variation in $\mathrm{C} / \mathrm{N}$ ratio, and the presence of metabolizable sugars, ions, and salts, in addition to other fermentation parameters including aeration level, pH, temperature, and incubation time [24,25,26]. Hence, it is essential to optimize production medium and cultivation conditions for the growth and enzyme production, in order to obtain high and commercial yields of alkaline protease.

\subsubsection{Effect of carbon source}

The influence of different carbon sources, including mono-, di- and polysaccharides, on the cells growth and production of alkaline protease was investigated. The results indicated that different carbon sources have a different impact on the production of extracellular protease from Bacillus sp. NPST-AK15. All tested carbon sources supported the growth of strain NPST-AK15. However, among the various carbon sources, fructose was found to support maximum protease production (Fig. 4a). Protease production in the presence of glucose or maltose led to a drastic decrease in the enzyme production up to $16.3 \%$ and $18.1 \%$ of the maximum yield. In addition, the enzyme yield decreased to $25.5,27.3,44.9$, and $48.9 \%$ of the maximum production in case of wheat bran, galactose, xylose, and lactose, respectively. The production of alkaline protease was further monitored at various concentrations of fructose, as the best carbon source. As shown in Fig. 4b, both growth and alkaline protease production were increased by increasing the fructose concentration, with maximal bacterial growth and enzyme production observed at $2 \%$. Further increases in fructose concentration led to the decrease of the enzyme production. These results are in accordance with some previous studies which showed that some pure carbon sources, mainly glucose and maltose, inhibit protease production, owing to catabolite repression of protein biosynthesis $[25,27,28]$. The production of protease from moderately halophilic Pseudoalteromonas sp. strain CP76 [29], halophilic

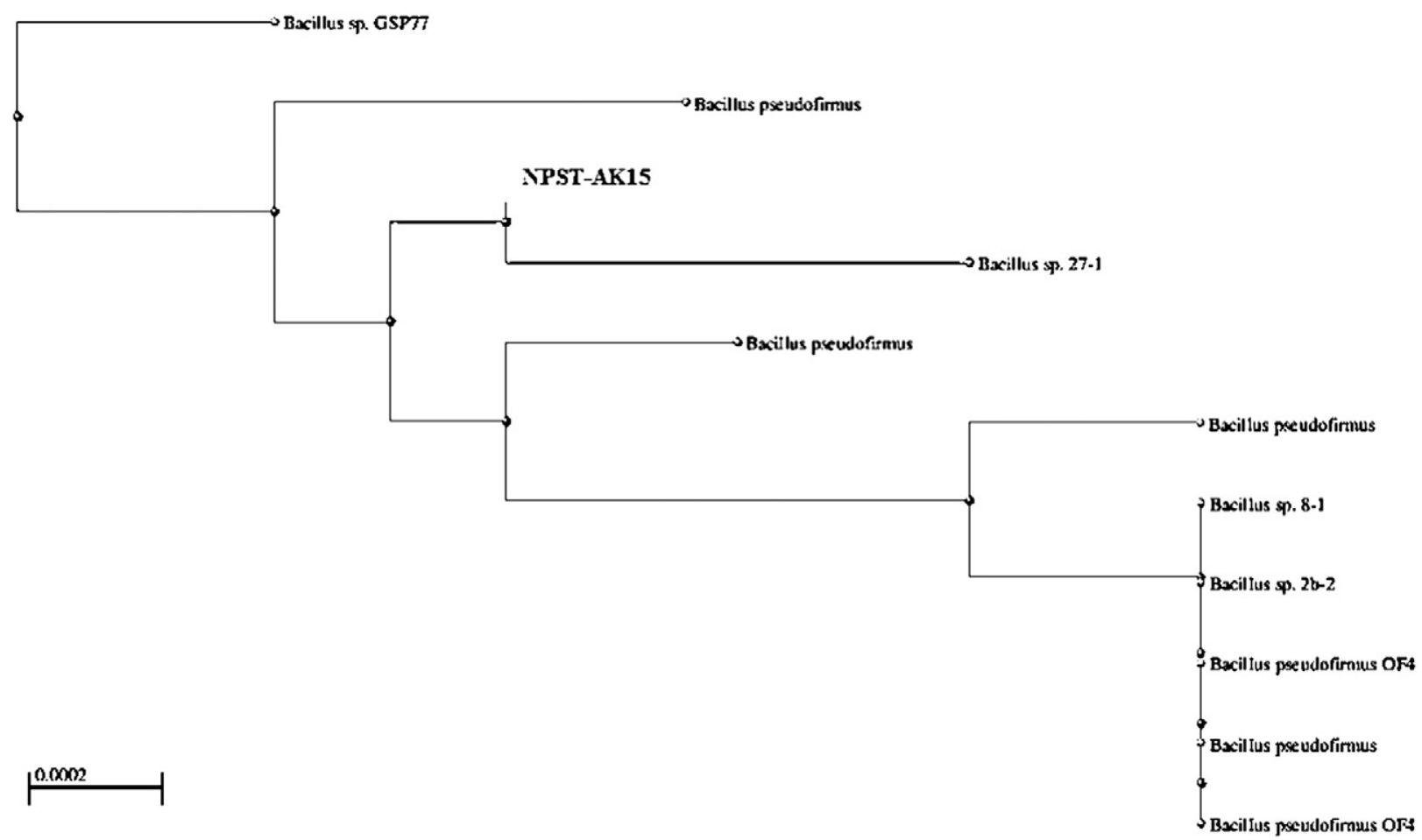

Fig. 3. Neighbor-joining phylogenetic tree of the isolated strain NPST-AK15 and its closest Bacillus strains based on $16 \mathrm{~S}$ rRNA gene sequences. 
a

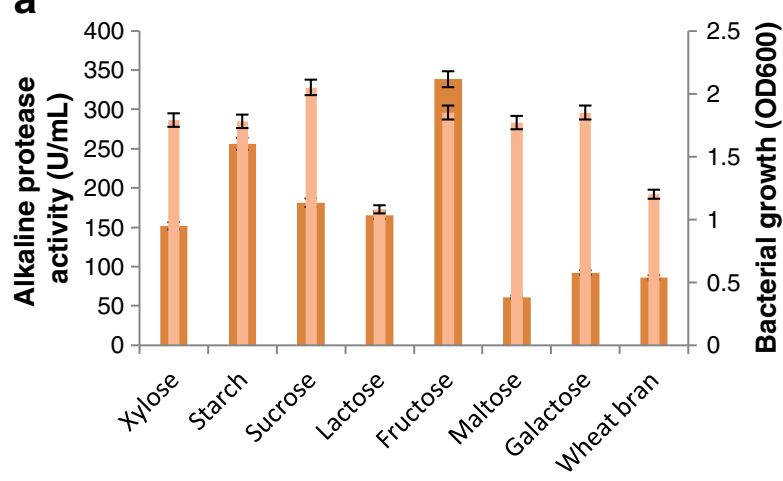

Carbon source

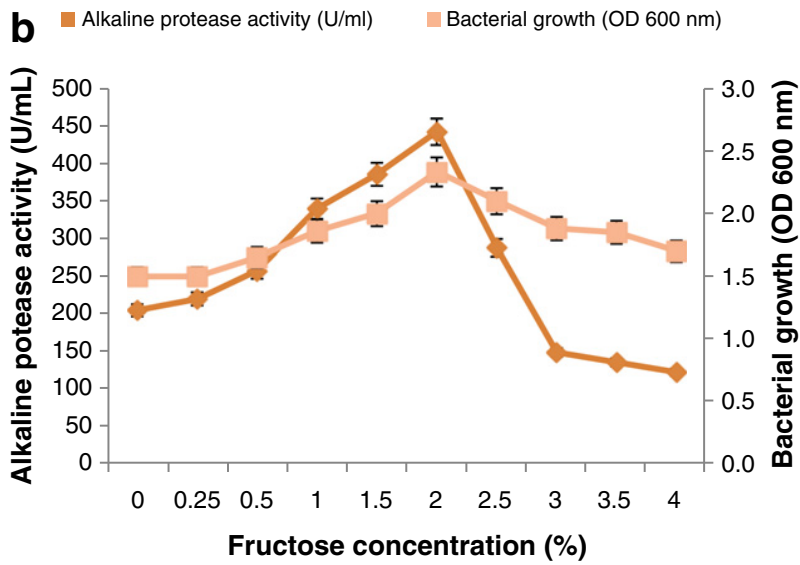

$\longrightarrow$ Alkaline protease activity $(\mathrm{U} / \mathrm{ml}) \quad$ Bacterial growth (OD $600 \mathrm{~nm})$

Fig. 4. (a) Effect of carbon sources $(0.5 \%, w / v)$ on growth and alkaline proteases production by strain NPST-AK15. Samples were taken after incubation of $24 \mathrm{~h}$ at $40^{\circ} \mathrm{C}$ under shaking conditions $(150 \mathrm{rpm})$, for the determination of bacterial growth and alkaline protease activity. Standard deviations $(n=3)$ are reported as error bars. (b) Effect of fructose concentration on bacterial growth and alkaline proteases production by strain NPST-AK15. Error bars represent the standard deviations $(n=3)$.

Bacillus S-20-9 [17] was significantly inhibited in the presence of maltose, glucose, and lactose. In addition, repressed growth and enzyme production at higher concentration of the substrates might be due the catabolic repression, or substrate inhibition, a traditional property of batch fermentation processes [30]. On the other hand, different carbon sources were reported for maximal protease production based on the organism of origin $[14,17,31]$.

\subsubsection{Effect of nitrogen source}

The influence of various nitrogen sources on the cells growth and alkaline protease production was evaluated using the production medium containing fructose as the sole carbon source. The results indicated that among the nitrogen sources used, several organic sources supported both growth and enzyme production by strain NPST-Ak15, with maximum yield in medium containing yeast extract, followed by skim milk, gelatin, casein, and other organic nitrogen sources, respectively (Fig. 5a). On the other hand, inorganic nitrogen sources proved to be unfavorable, where enzyme production yield drastically reduced to $0.0,0.5$, and $31 \%$ of the maximum output level, in case of ammonium nitrate, ammonium sulfate, or urea, respectively. This result was in agreement with that reported for marine Bacillus sp. MIG [32], alkaliphilic Bacillus pumilus MCAS8 [14], alkaliphilic Bacillus licheniformis KBDL4 [25], and Bacillus cluasii [33] where alkaline protease production was maximal using yeast extract, and significantly reduced using inorganic nitrogen sources. In earlier reports, it was found that other organic nitrogen sources supported
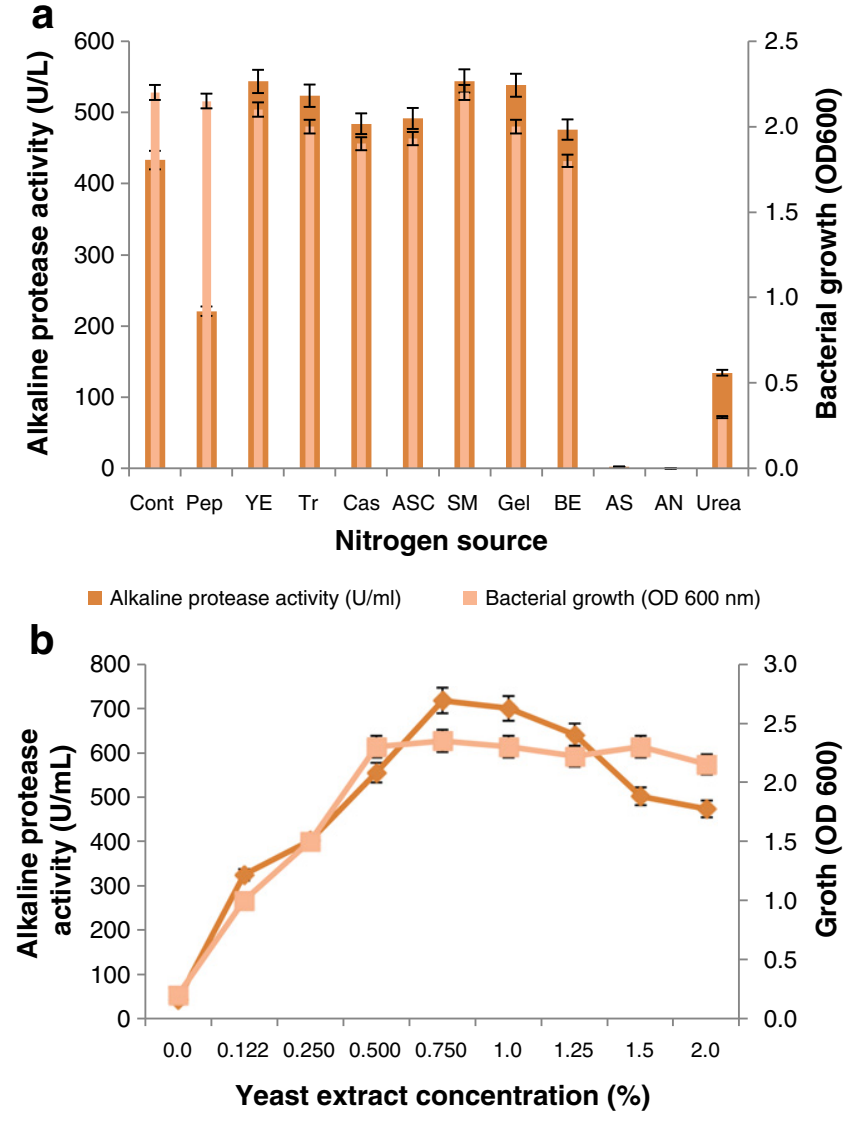

$\leadsto$ Alkaline protease activity $(\mathrm{U} / \mathrm{ml}) \quad$ Bacterial growth $(\mathrm{OD} 600 \mathrm{~nm})$

Fig. 5. (a) Effects of various nitrogen sources on cell growth and alkaline protease production by strain NPST-AK15, using fructose as a carbon source. Samples were taken after incubation of $24 \mathrm{~h}$ at $40^{\circ} \mathrm{C}$ under shaking conditions (150 rpm). Cont: Control; Pep: Peptone; YE: Yeast extract; Tr: Tryptone; Cas: Casein; ASC: Alkali soluble casein; SM: Skim milk; Gel: Gelatin; BE: Beef extract; AS: Ammonium sulfate; AN: Ammonium nitrate. Standard $(\mathrm{n}=3$ ) deviations are shown as error bars. (b) Effect of yeast extract concentration on bacterial growth and production of alkaline proteases by strain NPST-AK15. Standard deviations $(n=3)$ are indicated as error bars.

protease production in other microorganisms including skim milk [34], peptone [35], casamino acids [7], beef extract [10], and others, depending on the source organism [7,36,37]. The production of alkaline protease by strain NPST-Ak15 was further monitored at various concentrations of yeast extract. As shown in Fig. 5b, both growth and alkaline protease production were increased by increasing the yeast extract concentration, showing maximum enzyme yield at concentrations of $2 \%$. However, further increase of yeast extract led to a significant decrease in the enzyme production, with no effect on the bacterial growth. There are some reports on the repressive role of organic nitrogen sources and excessive amino acid and ammonium ions in alkaline protease production $[38,39]$.

\subsubsection{Effect of salinity}

The results presented in Fig. 6 show the influence of $\mathrm{NaCl}$ concentration on the cell growth and alkaline protease production by strain NPST-AK-15, which revealed that strain NPST-AK15 can grow over a wide range of $\mathrm{NaCl}$ concentrations from 0 to $20 \%$. However, maximal growth and enzyme production were seen in medium which contained $0-5 \%$ of $\mathrm{NaCl}$. Increasing the salt concentration to $7.5 \%$ caused a relative decrease in both bacterial growth and protease production to 78 and $85.9 \%$ of the maximal enzyme yield and cell growth, respectively. However, higher $\mathrm{NaCl}$ concentration led to a drastic reduction in both growth and protease production. The ability of strain NPST-AK15 to grow over a wide range of $\mathrm{NaCl}$ concentrations 


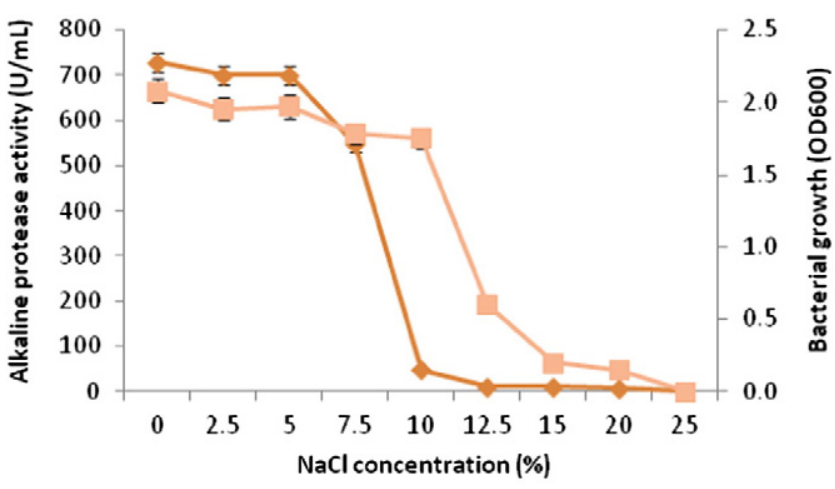

$\longrightarrow$ Alkaline protease activity $(\mathrm{U} / \mathrm{ml})-$ Bacterial growth $(\mathrm{OD} 600 \mathrm{~nm})$

Fig. 6. Effect of sodium chloride concentration on growth and production of alkaline proteases by strain NPST-AK15. Samples were taken after incubation of $24 \mathrm{~h}$ at $40^{\circ} \mathrm{C}$ under shaking conditions (150 rpm), for the determination of cell growth and protease activity. All experiments were carried out in triplicate and the mean values were recorded and the standard deviations $(\mathrm{n}=3)$ are indicated as error bars.

(0-20\%), with a maximum cell growth of $0-5 \%$, indicated the halotolerant nature of strain NPST-AK15 [7]. Previous studies on the effect of salinity on the growth of halotolerant bacteria have shown a change in the polar lipid composition of the cell membranes, and an increased salt concentration creates change in the lipid resulting in a decrease of growth rate causing reduced enzyme production [30]. Strain NPST-AK15 and its extracellular alkaline protease with salt tolerance signify their potential applicability in the laundry industry in a better way than the other reported proteases from Bacillus sp. $[6,7,40]$. Halophiles produce a large variety of stable and unique biomolecules that may be useful for practical applications. Halophilic microorganisms produce stable enzymes (including many hydrolytic enzymes such as DNAases, lipases, amylases, gelatinases and proteases) capable of functioning under conditions that lead to precipitation or denaturation of most proteins [12]. The high salt tolerance is also a characteristic feature of halophiles enzymes, which have a number of future applications in biotechnological process that depends on high salinity or osmotic pressures. In addition, halophilic proteins compete effectively with salts for hydration, a property that may result in resistance to other low-water-activity environments, such as in the presence of organic solvents. Novel halophilic biomolecules may also be used for specialized applications, e.g. bacteriorhodopsin for biocomputing, gas vesicles for bioengineering floating particles, pigments for food coloring, and compatible solutes as stress protectants $[15,16]$.

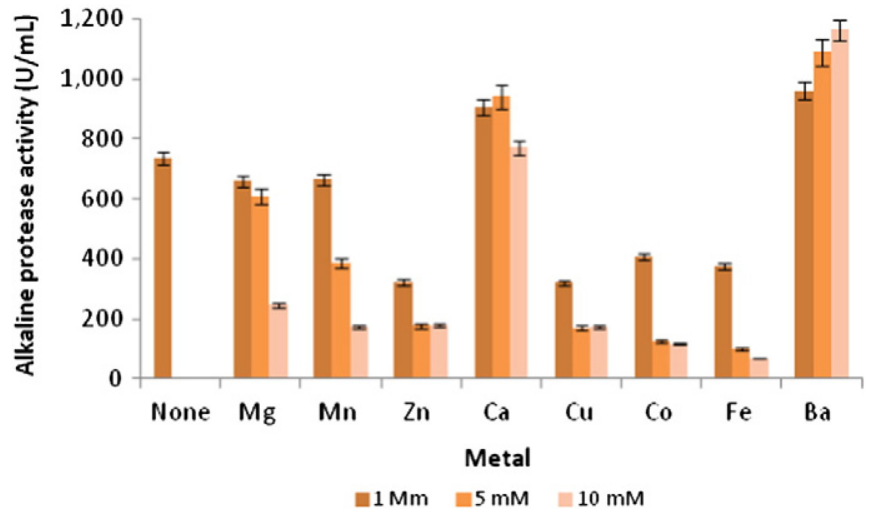

Fig. 7. Effects of various metal ions on alkaline protease production by strain NPST-AK15. The medium was supplemented with various metals at concentrations of $1 \mathrm{mM}, 5 \mathrm{mM}$ and $10 \mathrm{mM}$. Standard deviations $(\mathrm{n}=3)$ are indicated as error bars.

\subsubsection{Effect of metals ions}

The influence of various metal ions on cell growth and alkaline protease production was evaluated, and the results are demonstrated in Fig. 7. Among the cations tested $\mathrm{Ba}$ and $\mathrm{Ca}$ ions significantly enhanced the protease production by about 1.6 fold and 1.3 fold compared to the control, respectively. However, most of the other tested ions caused a significant reduction of the enzyme yield particularly at high concentration. Calcium ion has been reported to

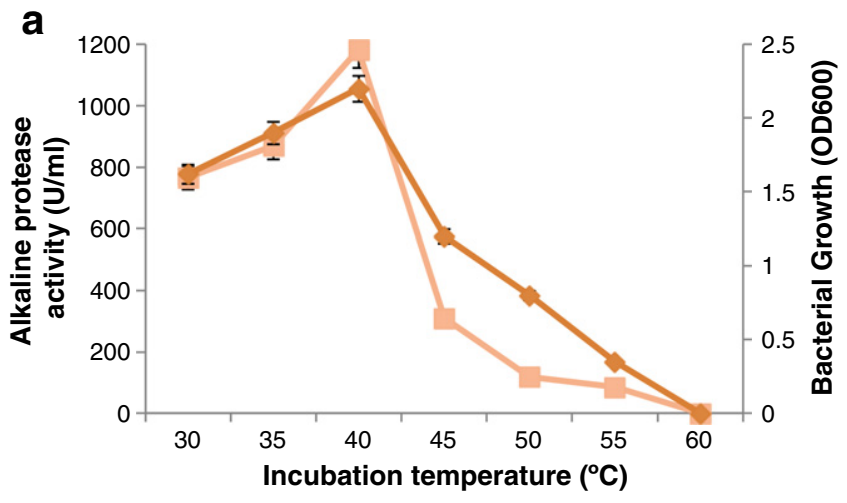

- Alkaline protease activity $(\mathrm{U} / \mathrm{ml}) \quad$ Bacterial growth $(\mathrm{OD} 600 \mathrm{~nm})$
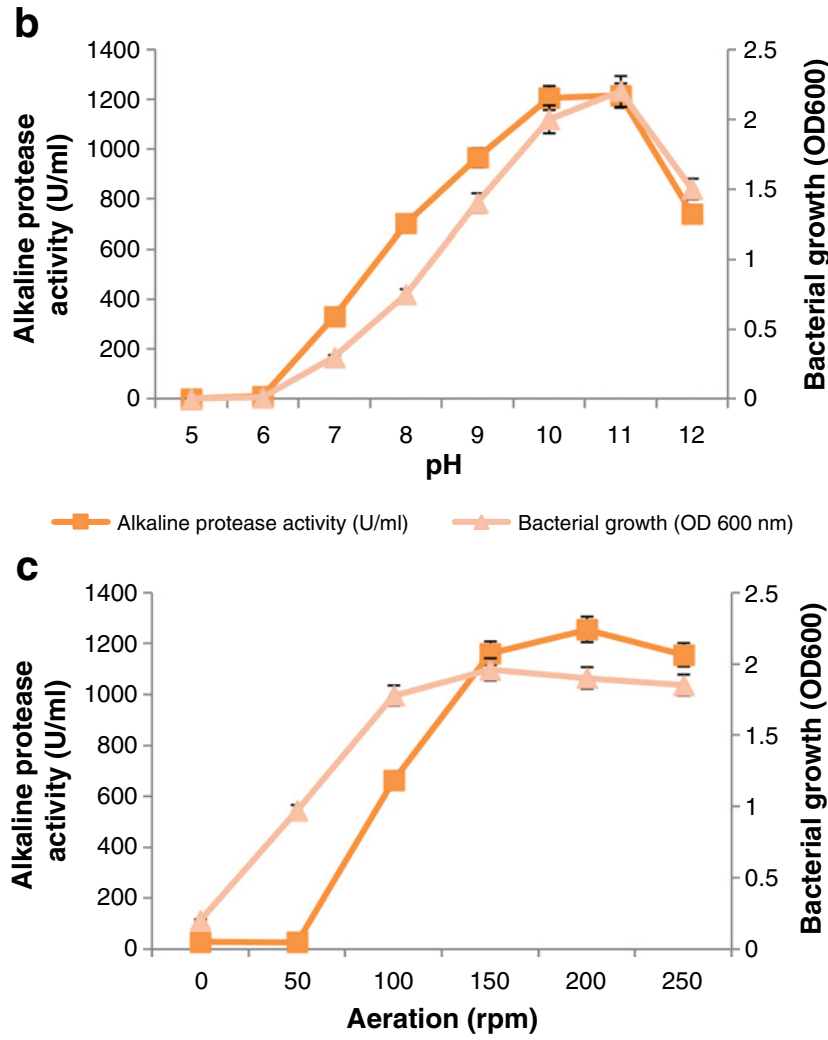

- Alkaline protease activity $(\mathrm{U} / \mathrm{ml}) \longrightarrow$ Bacterial growth $(\mathrm{OD} 600 \mathrm{~nm})$

Fig. 8. (a) Influence of growth temperature on cell growth and alkaline protease production by strain NPST-AK15. Cells were propagated under the optimized medium with $\mathrm{pH} 10$ and incubated at various growth temperatures for $24 \mathrm{~h}$ in orbital shaker (150 rpm). Error bars represent the standard deviations $(n=3)$. (b) Influence of $\mathrm{pH}$ on bacterial growth and alkaline protease production by strain NPST-AK15. Cells were propagated under the optimum temperature $\left(40^{\circ} \mathrm{C}\right)$ in media with different initial pH and incubated for $24 \mathrm{~h}$ in orbital shaker $(150 \mathrm{rpm})$. Error bars represent the standard deviations $(n=3)$. (c) Influence of aeration level (shaking rpm) on cell growth and alkaline protease production by strain NPST-AK15. Cells were propagated under the optimized medium with $\mathrm{pH} 10$ and incubated in shaking incubators with various rpm at $40^{\circ} \mathrm{C}$ for $24 \mathrm{~h}$. Standard deviations $(\mathrm{n}=3$ ) are seen as error bars. 
enhance protease production in several organisms [41,42]. In addition, Ba ion enhanced protease production by Bacillus sp. [43]. It has been reported that these metal ions protected the enzyme from thermal denaturation and maintained its active conformation at the high temperature [17]. On the other hand, supplementation of the medium with $\mathrm{Zn}, \mathrm{Cu}, \mathrm{Fe}$, and $\mathrm{Co}$ caused severe inhibition of protease production by NPST-AK15, particularly at high cation concentrations.

\subsubsection{Effect of incubation temperature, media $\mathrm{pH}$, and aeration level}

The effects of growth temperature, media $\mathrm{pH}$ and culture aeration are critical parameters affecting the bacterial growth and enzyme production [28,37]. Therefore, cell growth and alkaline protease production by strain NPST-AK15 were studied at various growth temperatures $\left(30-60^{\circ} \mathrm{C}\right)$. The optimum temperature for both alkaline protease production and cell growth was found to be at $40^{\circ} \mathrm{C}$ (Fig. 8a). There was a drastic decrease in the enzyme production at higher growth temperatures that the enzyme yield decreased to 26.2 and $10.1 \%$ of the maximum production at $45^{\circ} \mathrm{C}$ and $50^{\circ} \mathrm{C}$, respectively. Bacillus sp. NPST-AK15 can grow up to $55^{\circ} \mathrm{C}$ with no growth at $60^{\circ} \mathrm{C}$, indicating that this bacterium is a thermotolerant organism.

With respect to $\mathrm{pH}$, strain NPST-AK15 could grow and produce alkaline protease over a wide $\mathrm{pH}$ range from 7 to 12 , with maximal growth and enzyme production observed at pH 11 (Fig. 8b). At $\mathrm{pH} 5-7$, the bacterial growth and protease production were significantly reduced, which indicated the importance of growth $\mathrm{pH}$ in metabolic reactions which lead to the alkaline protease production in this bacterial strain. In addition the requirement of alkaline $\mathrm{pH}$ for optimum growth and protease production, clearly suggested an alkaliphilic nature of the organism and enzyme $[15,16]$. The optimum pH range between 9 and 10 for growth and protease production is common among alkaliphilic and haloalkaliphilic organisms [15,26,27,28].

Culture aeration is one of the most important parameters affecting microbial growth and enzyme production. The effect of the aeration level on bacterial growth and protease production by strain NPST-AK15 was investigated by incubating the cultures at various shaking speeds ranging from 0 to $250 \mathrm{rpm}$. As shown in Fig. 8c, the growth was drastically affected under static conditions and due to poor growth; protease production was reduced to less than $3 \%$ of the maximal enzyme yield. Both bacterial growth and enzyme production increased with an increasing aeration of up to $200 \mathrm{rpm}$, indicating the aerobic nature of NPST-AK15 and the importance of high-level aeration for alkaline protease production by this isolate. This finding was in agreement with that reported for Halophilic Bacterium MBIC3303, that its growth was completely reduced under static condition [17].

\subsection{Growth kinetics and proteases production of strain NPST-AK15}

The production of alkaline proteases by strain NPST-AK15 was investigated during $48 \mathrm{~h}$ of cultivation under the optimized medium compositions and conditions. As shown in Fig. 9 after about $4 \mathrm{~h}$ of lag phase, the growth was exponential up to $26 \mathrm{~h}$ followed by a stationary phase. Alkaline protease secretion was coherent with the growth pattern, and increased with the increasing growth, which started at the beginning of the exponential phase (8-10 h), and was maximal in the mid stationary phase with the highest activity recorded at $36 \mathrm{~h}(1263.3 \mathrm{U} / \mathrm{mL})$. After that, the enzyme production remained nearly constant at the maximal level along with the stationary phase of up to $40 \mathrm{~h}$. This secretion pattern of alkaline protease is quite similar to haloalkaliphilic Bacillus sp. Po2 [24] and alkaliphilic Bacillus sp. B001 [25], where maximal protease production was detected at the stationary phase. However, protease section by B. pumilus MCAS8 was found to be at late stationary phase (48 h) [14]. These findings on the production of the enzyme during stationary phase clearly suggest the prominent role of extracellular proteases in ecological sustenance, metabolism and survival of this organism [17,24].

\section{Conclusion}

A new potent alkaline protease producing halotolerant alkaliphilic isolate NPST-AK15 was isolated from hyper saline soda lakes of Wadi El-Natrun Valley, located in northern Egypt. The organism was affiliated to Bacillus sp. based on biochemical tests and 16S rRNA gene analysis. The characterization of NPST-AK15 indicated that this bacterium is halotolerant, thermotolerant and alkaliphilic in nature. Optimization of various fermentation parameters resulted in an increase of enzyme production yield by about 22.8 fold, indicating the significance of optimization of the fermentation process to obtain commercial yield of the enzyme. Alkaline protease secretion was coherent with the growth pattern, showing maximum enzyme production in mid stationary phase. NPST-AK15 and its extracellular alkaline protease with salt, $\mathrm{pH}$, and temperature tolerance signify their potential applicability in the laundry industry and other applications of alkaline protease. Complete purification and characterization of alkaline protease from NPST-AK15 are in progress to be published.

\section{Conflicts of Interest Statement}

The authors certify that they have no affiliations with or involvement in any organization or entity with any financial interest or non-financial interest in the subject matter or materials discussed in this manuscript.

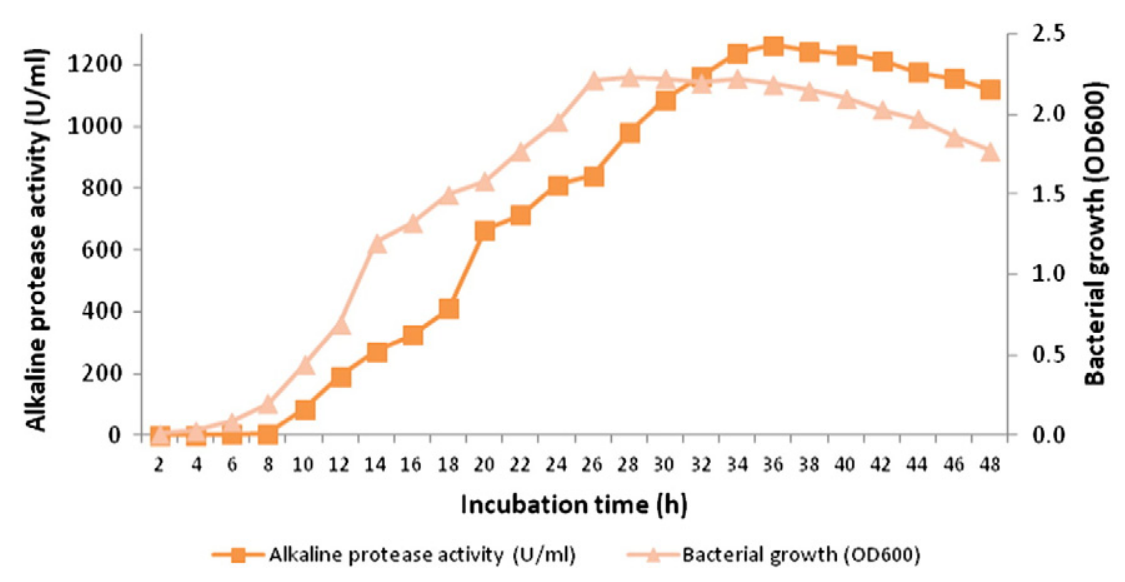

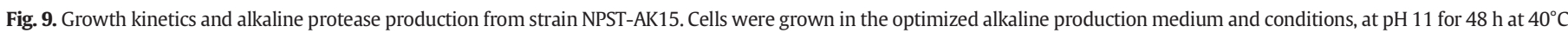
and $150 \mathrm{rpm}$. Samples were withdrawn at $2 \mathrm{~h}$ interval for the determination of cell growth. Standard deviations $(\mathrm{n}=3)$ were in a range of 1 to $3 \%$. 


\section{Financial support}

This Project was funded by the National Plan for Science, Technology and Innovation, King Abdulaziz City for Science and Technology, Kingdom of Saudi Arabia, Award Number (12-BIO2899-02).

\section{References}

[1] Shankar S, Rao M, Laxman RS. Purification and characterization of an alkaline protease by a new strain of Beauveria sp. Process Biochem 2011;46:579-85. http://dx.doi.org/10.1016/j.procbio.2010.10.013.

[2] Sundararajan S, Kannan CN, Chittibabu S. Alkaline protease from Bacillus cereus VITSN04: Potential application as a dehairing agent. J Biosci Bioeng 2011;111: 128-33. http://dx.doi.org/10.1016/j.jbiosc.2010.09.009.

[3] Annamalai N, Rajeswari MV, Balasubramanian T. Extraction, purification and application of thermostable and halostable alkaline protease from Bacillus alveayuensis CAS 5 using marine wastes. Proteins Struct Funct Bioinf 2014;92: 335-42. http://dx.doi.org/10.1016/j.fbp.2013.08.009.

[4] Haddar A, Bougatef A, Agrebi R, Sellami-Kamoun A, Nasri M. A novel surfactantstable alkaline serine-protease from a newly isolated Bacillus mojavensis A21. Purif Charac Process Biochem 2009;44:29-35. http://dx.doi.org/10.1016/j.procbio.2008.09.003.

[5] Raval VR, Pillai S, Rawal CM, Singh SP. Biochemical and structural characterization of a detergent-stable serine alkaline protease from seawater haloalkaliphilic bacteria. Process Biochem 2014;49:955-62. http://dx.doi.org/10.1016/j.procbio.2014.03.014.

[6] Haddar A, Agrebi R, Bougatef A, Hmidet N, Sellami-Kamoun A, Nasri M. Two detergent stable alkaline serine-proteases from Bacillus mojavensis A21: Purification, characterization and potential application as a laundry detergent additive. Bioresour Technol 2009;100:3366-73. http://dx.doi.org/10.1016/j.biortech.2009.01.061.

[7] Jain D, Pancha I, Mishra SK, Shrivastav A, Mishra S. Purification and characterization of haloalkaline thermoactive, solvent stable and SDS-induced protease from Bacillus sp.: A potential additive for laundry detergents. Bioresour Technol 2012;115:228-36. http://dx.doi.org/10.1016/j.biortech.2011.10.081.

[8] Joshi S, Satyanarayana T. Characteristics and applications of a recombinant alkaline serine protease from a novel bacterium Bacillus lehensis. Bioresour Technol 2013; 131:76-85. http://dx.doi.org/10.1016/j.biortech.2012.12.124.

[9] Shah K, Mody K, Keshri J, Jha B. Purification and characterization of a solvent, detergent and oxidizing agent tolerant protease from Bacillus cereus isolated from the Gulf of Khambhat Kunal. J Mol Catal B Enzym 2010;67:85-91. http://dx.doi.org/10.1016/j.molcatb.2010.07.010.

[10] Kumar RS, Ananthan G, Prabhu AS. Optimization of medium composition for alkaline protease production by Marinobacter sp. GA CAS9 using response surface methodology - A statistical approach. Biocatal Agric Biotechnol 2014;3:191-7. http://dx.doi.org/10.1016/j.bcab.2013.11.005.

[11] Vijayaraghavan P, Vincent SGP. Cow dung as a novel, inexpensive substrate for the production of a halo-tolerant alkaline protease by Halomonas sp. PV1 for eco-friendly applications. Biochem Eng J 2012;69:57-60. http://dx.doi.org/10.1016/j.bej.2012.08.014

[12] Horikoshi K. Past, present and future of extremophiles. Extremophiles 2008;12:1-2 http://dx.doi.org/10.1007/s00792-007-0127-5.

[13] Gohel SD, Singh SP. Thermodynamics of a $\mathrm{Ca}^{2+}$-dependent highly thermostable alkaline protease from a haloalkaliphilic actinomycete. Int J Biol Macromol 2015, 72:421-9. http://dx.doi.org/10.1016/j.ijbiomac.2014.08.008.

[14] Jayakumar R, Jayashree S, Annapurna B, Seshadri S. Characterization of thermostable serine alkaline protease from an alkaliphilic strain Bacillus pumilus MCAS8 and its applications. Appl Biochem Biotechnol 2012;168:1849-66. http://dx.doi.org/10.1007/s12010-012-9902-6.

[15] Horikoshi K. Alkaliphiles: Some applications of their products for biotechnology. Microbiol Mol Biol Rev 1999;63:735.

[16] Horikoshi K, Antranikian G, Bull AT, Robb FT, Stetter KO, editors. Extremophiles Handbook, vol. 1 - 2. Berlin: Springer; 2011.

[17] Joshi RH, Dodia MS, Singh SP. Production and optimization of a commercially viable alkaline protease from a Haloalkaliphilic bacterium. Biotechnol Bioprocess Eng 2008; 13:552-9. http://dx.doi.org/10.1007/s12257-007-0211-9.

[18] Taher AG. Inland saline lakes of Wadi El Natrun depression Egypt. Int J Salt Lake Res 1999;8:149-69. http://dx.doi.org/10.1007/BF02442128.

[19] Smibert RM, Krieg NR. Phenotypic characterization. In: Gerhardt P, Murray RGE, Wood WA, Krieg NR, editors. Methods for General and Molecular Bacteriology. Washington, DC: American Society for Microbiology; 1994. p. 607-54.
[20] Lane DJ. 16S/23S rRNA sequencing. In: Stackebrandt E, Goodfellow M, editors. Nucleic Acid Techniques in Bacterial Systematic. New York: John Whiley, Sons; 1991. p. $115-75$

[21] Osborne CA, Galic M, Sangwan P, Janssen PH. PCR-generated artifact from 16S rRNA gene-specific primers. FEMS Microbiol Lett 2005;248:183-7.

[22] Kembhavi AA, Kulkarni A, Pant A. Salt-tolerant and thermostable alkaline protease from Bacillus subtilis NCIM No. 64. Appl Biochem Biotechnol 1993;38:83-92. http://dx.doi.org/10.1007/BF02916414.

[23] Hmidet N, Ali NA, Haddar A, Kanoun S, Alya SK, Nasri M. Alkaline proteases and thermostable $\alpha$-amylase co-produced by Bacillus licheniformis $\mathrm{NH} 1$ : Characterization and potential application as detergent additive. Biochem Eng J 2009;47:71-9. http://dx.doi.org/10.1016/j.bej.2009.07.005.

[24] Patel RK, Dodia MS, Joshi RH, Singh SP. Production of extracellular halo-alkaline protease from a newly isolated haloalkaliphilic Bacillus sp. isolated from seawater in Western India. World J Microbiol Biotechnol 2006;22:375-82. http://dx.doi.org/10.1007/s11274-005-9044-X.

[25] Deng A, Wu J, Zhang Y, Zhang G, Wen T. Purification and characterization of a surfactant-stable high-alkaline protease from Bacillus sp. B001. Bioresour Technol 2010;101:7100-6. http://dx.doi.org/10.1016/j.biortech.2010.03.130.

[26] Patel R, Dodia M, Singh SP. Extracellular alkaline protease from a newly isolated haloalkaliphilic Bacillus sp.: Production and optimization. Process Biochem 2005; 40:3569-75. http://dx.doi.org/10.1016/j.procbio.2005.03.049.

[27] Kanekar PP, Nilegaonkar SS, Sarnaik SS, Kelkar AS. Optimization of protease activity of alkaliphilic bacteria isolated from an alkaline lake in India. Bioresour Technol 2002;85:87-93. http://dx.doi.org/10.1016/S0960-8524(02)00018-4.

[28] Pathak AP, Deshmukh KB. Alkaline protease production, extraction and characterization from alkaliphilic Bacillus licheniformis KBDL4: A Lonar soda lake isolate. Indian J Exp Biol 2012;50:569-76.

[29] Meena P, Tripathi AD, Srivastava SK, Jha A. Utilization of agro-industrial waste (wheat bran) for alkaline protease production by Pseudomonas aeruginosa in SSF using Taguchi (DOE) methodology. Biocatal Agric Biotechnol 2013;2:210-6. http://dx.doi.org/10.1016/j.bcab.2013.05.003.

[30] Chandran S, Madhavan NK, Ashok P. Microbial proteases. In: Barredo JL, editor. Microbial Enzymes and Biotransformations, vol. 17. Humana Press; 2005. p. 165-79.

[31] Shivanand P, Jayaraman G. Production of extracellular protease from halotolerant bacterium, Bacillus aquimaris strain VITP4 isolated from Kumta coast. Process Biochem 2009;44:1088-94. http://dx.doi.org/10.1016/j.procbio.2009.05.010.

[32] Sánchez-Porro C, Mellado E, Bertoldo C, Antranikian G, Ventosa A. Screening and characterization of the protease $\mathrm{CP} 1$ produced by the moderately halophilic bacterium Pseudoalteromonas sp. strain CP76. Extremophiles 2003;7:221-8. http://dx.doi.org/10.1007/s00792-003-0316-9.

[33] Lakshmi BKM, Sri PVR, Devi KA, Hemalatha KPJ. Screening, optimization of production and partial characterization of alkaline protease from haloalkaliphilic Bacillus sp. Int J Res Eng Technol 2014;3:435-45.

[34] Gouda MK. Optimization and purification of alkaline proteases produced by marine Bacillus sp. MIG newly isolated from eastern harbour of Alexandria. Pol J Microbiol 2006;55:119-26.

[35] Oskouie SFG, Tabandeh F, Yakhchali B, Eftekhar F. Response surface optimization of medium composition for alkaline protease production by Bacillus clausii. Biochem Eng J 2008;39:37-42. http://dx.doi.org/10.1016/j.bej.2007.08.016.

[36] Uyar F, Porsuk I, Kizil G, Yilmaz EI. Optimal conditions for production of extracellular protease from newly isolated Bacillus cereus strain CA15. Eur Asian J Biol Sci 2011;5: 1-9. http://dx.doi.org/10.5053/ejobios.2011.5.0.1.

[37] Srividya S, Mala M. Influence of process parameters on the production of detergent compatible alkaline protease by a newly isolated Bacillus sp. Y. Turk J Biol 2011;35: 177-82. http://dx.doi.org/10.3906/biy-0906-47.

[38] Joo HS, Kumar CG, Park GC, Paik SR, Chang CS. Oxidant and SDS-stable alkaline protease from Bacillus clausii I-52: Production and some properties. J Appl Microbiol 2003;5:267-72. http://dx.doi.org/10.1046/j.1365-2672.2003.01982.x.

[39] Chu WH. Optimization of extracellular alkaline protease production from species of Bacillus. J Ind Microbiol Biotechnol 2007;34:241-5. http://dx.doi.org/10.1007/s10295-006-0192-2.

[40] Gupta R, Beg Q, Khan S, Chauhan B. An overview on fermentation, downstream processing and properties of microbial alkaline proteases. Appl Microbiol Biotechnol 2002;60:381-95. http://dx.doi.org/10.1007/s00253-002-1142-1.

[41] Chauhan B, Gupta R. Application of statistical experimental design for optimization of alkaline protease production from Bacillus sp. RGR-14. Process Biochem 2004; 39:2115-22. http://dx.doi.org/10.1016/j.procbio.2003.11.002.

[42] Nadeem M, Qazi JI, Baig S, Syed QUA. Studies on commercially important alkaline protease from Bacillus licheniformis N-2 isolated from decaying organic soil. Turk J Biol 2007;32:171-7.

[43] Nascimento WCA, Martins MLL. Production and properties of an extracellular protease from Thermophilic Bacillus sp. Braz J Microbiol 2004;35:91-6. http://dx.doi.org/10.1590/S1517. 